\title{
P257: Survey of the prevalence of healthcare associated infection at the Sahloul-Sousse teaching hospital-2010
}

\author{
D Chebil', S Khefacha Aissa, H Said Latiri, M Ben Rejeb, N Jaidane, M Miladi, L Dhidah \\ From 2nd International Conference on Prevention and Infection Control (ICPIC 2013) \\ Geneva, Switzerland. 25-28 June 2013
}

\section{Introduction}

The hospital hygiene service of the Sahloul Sousse Teaching Hospital (Tunisia) set up a surveillance system, based on regular prevalence surveys.

\section{Objectives}

To monitor the prevalence of healthcare associated infections (HAI) in all services.

\section{Methods}

The survey was carried in April 2010 to assess the prevalence of HAI and identify any risk factors. The data was collected on a given day for each hospital service and all services were monitored within the same week.

\section{Results}

The survey concerned 352 patients with an average age of $48 \pm 24$ years. $7.7 \%$ of patients had an infection, the prevalence of HAI being $38.5 \%$. The intensive care services had the highest HAI rate followed by the surgical services and medical services. $42 \%$ of patients had a predisposition to infection. The most common extrinsic risk factors significantly related to HAI were parenteral nutrition, central venous catheters and urinary catheters. Pulmonary infections were the most common, followed by urinary tract infections, bacteremia and surgical site infections. The microorganisms most frequently implicated in the HAIs were Gram-negative bacteria $(85 \%, n=21)$ including Enterobacter cloacae, Acinetobacter baumanii, Klebsiella pneumonia, Escherichia Coli and Pseudomonas aeruginosa.

Microbiology Laboratory, Department of Hygiene and Service reanimation, Hospital of Sahloul, Sousse, Tunisia

\section{Conclusion}

Monitoring HAI in this hospital helped to determine the priorities for corrective and preventive actions according to the problems identified.

\section{Competing interests}

None declared.

Published: 20 June 2013

doi:10.1186/2047-2994-2-S1-P257

Cite this article as: Chebil et al:: P257: Survey of the prevalence of healthcare associated infection at the Sahloul-Sousse teaching hospital2010. Antimicrobial Resistance and Infection Control 2013 2(Suppl 1):P257.
Submit your next manuscript to BioMed Central and take full advantage of:

- Convenient online submission

- Thorough peer review

- No space constraints or color figure charges

- Immediate publication on acceptance

- Inclusion in PubMed, CAS, Scopus and Google Scholar

- Research which is freely available for redistribution
C Biomed Central 